\title{
Development and Religious Social Ethtics of the Major World Religions
}

\author{
Lewis Bwalya Chilufya $^{1^{*}} \quad$ Prosper Ng'andu $^{2} \quad$ Beatrice Mumbi M. $^{3}$ \\ 1. University of Kwame Nkrumah University, P.O. Box 8040 Kabwe, Zambia \\ 2. University of Zambia, Great East Road Campus P.O. Box 32379 Lusaka, Zambia \\ 3. Mulungushi University, Great North Road Campus, P.O. Box 80415, Kabwe, Zambia
}

\begin{abstract}
Development, in human history, has been driven by various factors. Some of these have sheer human ingenuity and pressure to survive through the demands of different kinds of environment and circumstance. In any case, there have been certain values that have constantly informed human activity and strides. Such values have included social ethics of the major world religions.In this article, we have focused on how the values of social ethics of the world's major religions inform development in so far as they exert control on human conduct, and which, in turn, either propel or hinder the agenda of development. On this basis, we have ultimately argued that development of countries and societies are interlocked with social ethics of these religious values. As such, these values should always be given a voice in deliberations regarding policymaking and politics surrounding the subject of development of countries and societies.
\end{abstract}

Keywords: Religion, Development, Policymaking, Social, Ethics, Values

DOI: $10.7176 /$ JPID/57-04

Publication date: December $31^{\text {st }} 2020$

\subsection{Introduction}

Development has taken various trajectories in the course of history. Humanity has advanced through various ages that can be traced from the Stone Age, Iron Age, Enlightenment Age, Industrial Age, and to the Information and Digital Ages of our times that has been given impetus by COVID-19 pandemic. Whereas these advancements have been driven by both human ingenuity and sheer pressure to survive through the exigencies of different kinds of environment and circumstance, certain values have constantly informed human activity and strides. Such values have included, among others, social, ethical, philosophical, political, scientific and religious and social ethics of the major world religions. Actors in development agendas of countries and societies may have overlooked some of these values.

In this article, we have particularly focused on how the values of social ethics of the world's major religions inform development in so far as they regulate human conduct. In doing so, we have demonstrated the extent to which social ethics of these religions has either propelled or hindered the agenda of development. On this basis, we have ultimately argued that religion is interlocked with development in that social ethics of world religions has been an enduring force for both the successes and failures of development. Thus, since religion is an essential aspect of human life, this article demonstrates that religious social ethical values should always be accorded a voice in discussions regarding policymaking and politics surrounding the subject of development of countries and societies.

\subsection{Notion of Development}

Development, as a term, has been associated with various meanings. This is because it is "complex, contested, ambiguous, and elusive" (https://www.soas.ac.uk/cedep-demos/000_P501_USD_K3736-Demo). From the standpoint of the world religious institutions, the desire has been that this concept has to be all-embracing as opposed to limiting it to material progress. In this sense, it should encompass social, political, environmental, environmental, cultural, spiritual and economic facets of human life. On this score, we have subscribed to the understanding that development is "is a process which results in the transformation of social structures in a manner which improves the capacity of society to fulfill its aspirations" (Welch and Corner 2004:23). This notion, in our view, inevitably tallies with the conception of society as a composition of individuals, with all their individual and collective needs to fulfill their potentials and aspirations.

Development involves ongoing activities and engagements that engender social change, which in turn provides conditions in which people can attain their potentials. Consequently, UNESCO (2003) defined development as not only purely an economic phenomenon, but also as a multi-dimensional process, which involves re-organization and re-orientation of the entire economic, social and political sectors. As such, development is a phenomenon that goes beyond interactions among human beings in that it also includes the relations between human beings and their natural environment. In this respect, it involves a process by which natural resources are converted into cultural resources. Although this process of conversion has generally increased in pace and complexity with time, it has arguably taken place throughout the history of human societies 
https://www.soas.ac.uk/cedep-demos/000 P501 USD K3736-Demo).As such, the affirmation of this aspect of natural environment in the conception of development lends weight to Maider's (2010) description of it as the overall collective socio-economic, sustainable, cultural, political as well as religious advancement of a country. Having established the meaning of development, we can already note that religion is encompassed in this comprehensive understanding. For this reason, this conception constitutes the background against which our treatment of the interplay between development and religious social ethics will hinge in this article.

\subsection{Religion as a Societal Phenomenon}

All major world religions have an inherent social aspect due to the moral conduct that they demand of their adherents. This is true of Christianity, Islam, Buddhism, and Hinduism. Though they represent beliefs in nonempirically determined reality or forces (usually referred to as God or gods), they have significant influence on human behavior whose effects affect other human beings. This is unavoidable because as human beings we are essentially social or relational. At any rate, religious faith manifests itself in the daily empirical reality. This stems from the fact that religion provides human existence with ultimate meaning. This reality is evident from the perspective of the religions under discussion.

\subsection{Christianity}

From the outset, we must concede that Christianity is not a homogeneous faith tradition. According to Preston (1993), it is fragmented into five broad confessional traditions. These are the Orthodox (primarily in Eastern Europe and Russia), the Roman Catholic (the most numerous), the Lutheran, the Calvinist or Reformed (also known as the Presbyterian, Congregationist and Baptist in the English-speaking world), the Anglican (including its offshoot Methodism). In any case, Christian social ethics draws its insights chiefly from four sources. These are the Bible, Christian Tradition, philosophy, scientific knowledge, and general human experience (Macquarrie and Childress, 1986).

Based on the above sources of Christian social ethics, respect for every human being solely as a person, created in God's image, emerges as the fundamental principle of Christian social ethics. This calls for the recognition of the dignity of every human person - regardless of all social stratification, possession or legislation. This is because every human being is deemed to be a child of God, and has been created in God's own image. This element of faith entails fundamental equality of human beings. For this reason, Christian social ethics has generally tended to emphasize the need for love (agape) for all human beings as creatures of the same God. Jesus Christ himself, who is the epitome and summit of Christian divine revelation, summarizes the Torah (the first five books of the Old Testament or Hebrew Scriptures) as love of God and neighbor (Matthew 22:34ff).

The human person commands primary consideration in Christian social ethics as opposed to society. For this reason, the State exists for the citizen, not the other way round (Temple 1942). This principle, therefore, requires respect for individuals' right to freedom so that they can fulfil their potentialities in a responsible manner and in self-giving relationships with other human beings and God. As relational, the human person called be compassionate, that is, to love God and others. Peschke $(1987,221)$ contended in affirmation of this conception of the human person in stating that "[c]oncern for society is concern for one's own welfare, concern for one's neighbor, and ultimately concern for that final goal which everyman, every community, and all mankind is called to serve and bring about: God's kingdom and glory." Hence, in the Catholic social teachings, including the process of development, the element of common good - the welfare of the entire group - is prominent (John Paul II, 1987).

At any rate, the role of political authority inevitably becomes one of ensuring that conditions are conducive for the human person to fulfil himself/herself. This is what then brings about authentic development. For as Temples (1942) argued, the primary aim of social progress is to give the fullest possible latitude for the existence of all powers and qualities, which are distinctly personal; and of these, the most fundamental is freedom or ability to make deliberate choices that human persons innately possess. Consequently, governments and public authorities have the duty of creating situations which are suitable for the free exercise of economic activity while at the same time protecting the weak (Pontifical Council for Justice and Peace, 2004). Doing so conforms to the understanding that "at the heart of the Christian faith is a social gospel, a call to respond to the needs of the world and those who occupy it (Marshall: 2008, xiii)." This insight affirms the existential reality of disparities among individuals in terms of opportunities and abilities to creatively fulfill themselves. Thus, other than the fairness of economic processes, Christian concept of economic just also requires that each person should have adequate access to resources, which are available in community, so that they can survive, develop, flourish and be able to in turn contribute to the community through their service (Hug, 2005).

Nonetheless, it is also worth noting that the proper exercise of freedom should not be arbitrarily. It requires aligning it with the moral law as provided by God. Furthermore, and as alluded to, there should be proper be right and just conditions of an economic, social, juridical, political and cultural order (Pontifical Council for Justice and Peace, 2004). As a result, Christianity has historically raised ethical questions ranging from personal to the complex economic and political ones such those of war and peace (Preston, 1993). 


\subsection{Islam}

Like Christianity, social ethics of Islam is rooted in the view that the divine command is the foundation for establishing a moral order through human endeavor (Nanji, 1993). However, the Islamic approach to ethical matters is not unified and monolithic due to the religion's plurality and diversity (chiefly in form of Sunni, Shi'a and Sufi Traditions) both in the past and in the present. As such, there is no one ethical response among various Muslim communities in the world can be regarded as normative for all Muslims. Notwithstanding this element, Islam draws its primary authority for this kind of response from the Quran.

In this light, Islam stresses good works, social justice and moral strategies for addressing questions of poverty and imbalance in wealth. It promotes works such as paying alms tax, helping the needy, enduring in difficulty times, keeping promises, and avoiding wastage. In this way, Islam subscribes to the value of the common good due to its bias towards community and social justice. Besides, the Universal Declaration of Human Rights in Islam (1981) resonates well with the United Nations Charter and Universal Declaration of Human Rights (Macquarrie and Childress, 1986). Without doubt, these fundamental tenets of international law guarantee protection of people, ensure their material and spiritual well-being as well as development of societies (Reus-Smit and Snidal, 2008).

\subsection{Buddhism}

Buddhism, a religion that was founded by the Buddha, has a strong social sense. According to Macquarrie and Childress $(1986,66)$, “[t]he Buddha's teaching included both a diagnosis of the condition of human beings and a prescription on how that condition could be alleviated and finally cured". The prescription he gave was the Nobel Eightfold Path that includes, among others, right speech, right action and right livelihood. Furthermore, the Five Precepts of Buddhism enjoins upon both lay people and monks to respect and help the community through pious works such as sharing of food, giving alms and providing shelter and caring for the poor. These two aspects of Buddhism, coupled with its ideal of compassion, constitute the bedrock of the Buddhist programme of social justice (Macquarrie and Childress, 1986).More still, Buddhism places premium on the idea of reciprocity in human relations, and rejects caste and race discrimination (De Silvia, 1993). As such, Buddhism provides something that is true of most major religions: disciplines, values and directives that a person may want to live by.

As explained by De Silvia (1993), the ideal that the Buddha offers for man in following his ethical system is the moral ideal of happiness (nibbana). For laypeople, nibbana is attained by living by the five precepts of Pancasila: no killing, stealing, lying, sexual misconduct, or intoxicants. These prohibitions constitute basic requirements for living a good moral life and establishing a good community. Besides, the layman is entitled to own property and to accumulate wealth so as to have a decent existence for his family. In so doing, however, the layman is obliged to avoid developing greed and avarice for wealth. Incidentally, the first percept entails noninjury or non-violence to all living creatures from the lowest insect to humans. It calls for a non-violent attitude regarding every living being. This attitude stems from the perception of the interconnectedness of all living beings that evokes in every human beings responsibility towards the rest, a sense that is akin to Christian and Islamic concepts of the common good.

\subsection{Hinduism}

Hinduism, which is an amalgamation of various religious and cultural elements in the Indian subcontinent, regards wealth and duty as the ends of human life that subserve the supreme goal of moksha (liberation or salvation from the cycle of rebirths). As such, social change and progress are viewed as practical and integral components of Hinduism (Macquarrie and Childress, 1986). As for virtues and moral values, the Vedic hymn is laden with certain humanistic virtues and moral ideals that govern social life of adherents of Hinduism. These values and moral ideas include truthfulness, giving, restraint, austerities, affection and gratitude, fidelity, forgiveness, not stealing, not cheating, giving others their just reward, and avoiding harm to all creatures (Bilimoria,1993).

Furthermore, Hinduism consists of a principle that governs the way society is organized and ordered. Bilimoria (1993) has contended that according to this principle, society is divided into four functional 'classes', which are known as varna (literally, 'color'). These are Brahmana (which has a religious, instructional function), Kshatriya (with sovereign and defense function), Vaishya (agriculture, economic function) and Shudra (with menial and labor function). Ideally, these differences in function do not entail difference in interests, rights and privileges. At any rate, Hindu society is divided further according to castes that are based on birth.

Having thus highlighted the key values of the social ethics of the selected major world religions, albeit not exhaustively, our stage is sufficiently set to delve into a discussion on their pros and cons with regard to development.

\subsection{Positive Role of Religious Social Ethics in Development}

Like other ideologies, it is reasonable to expect that the prevalence of religious faith traditions lay the foundation for individual and collective transformations. Their cosmological perspective, values and views about life, nature, evil, the sacred, and virtues, all these dictate human actions that either yield or impede social change and 
development.

From the standpoint of economic advancement, development entails an increase in the size or speed of the economy such that more products and services are produced (https://www.soas.ac.uk/cedepdemos/000_P501_USD_K3736-Demo/unit1). This is attained through utilization of raw materials and energy from the natural environment. Inevitably, because conversion processes are never fully efficient, some waste is produced which is usually discarded into the environment as various kinds of pollution and toxification. The effects of such economic activity include loss of soil, eutrophication of water, desertification, depletion of forests, overfishing and food insecurity. In their wake, moral insights and persuasive force of world religions run counter by insisting on the reframing of Human-Earth relations (Tucker, 2005).

According to Harris (1975), there are values and beliefs that shape the relationship of people to their natural environment and the way they manage and impact it. The logical conclusion of this line of thought is that economic activity is never free of value. There personal or collective biases, such as beliefs, which accompany economic activity. On this score, religion may actually declare the proper relation of the economic endeavors to other human activities. This is because social order is itself not devoid of values. On the contrary, it is inextricably embedded with values that are active in the minds of citizens from one generation to another (Temple, 1942).

Notwithstanding, religion cannot claim to know what will be the purely economic effect of particular proposals. Such matters are competently handled by technological experts of particular secular fields such as economics and politics. (Pontifical Council for Justice and Peace, 2004). As such, religion only claims the privilege to call attention to values that are higher than economic issues that require technical knowledge and practical experience.

Incidentally, the origins of several development organizations attest to the religious value base that underlies societies in which they emerged. This is especially true of numerous civil society organizations (CSOs) such NonGovernmental Organizations (NGOs), Non-Profits and Not-for Profit civil society organizations such as Christian Aid, Caritas, Christian Relief Services (CRS), ACEMS-MISSION, Catholic Agency For Overseas Development (CAFOD), and World Vision. In the case of Zambia, and many other developing countries, these are among key organizations which have been working toward achieving the Sustainable Development Goals (SDGs) and the ultimate attainment of the much needed development (http://www.panos.org.zm/index.php/2018/04/18/towardsachieving-sustainable-development-goals-in-zambia-the-role-of-civil-society-organisations).

Generally, however, it also should be noted that religious faith, especially in developing countries, manifests itself in the public domain because secular daily life involves an overlap with religious beliefs. As such, it "is paramount for development practitioners to understand how a religion works and how the religious believer sees the world and establishes development priorities and outcomes (Religion \& Development Practitioners' Guide: 2011, p.9)."

Essentially, development requires specific conditions for it to occur. These arguably include religious orientations in that development cooperation usually occurs among people for whom religious identity and beliefs are very significant. This religious element plays a critical role in that they determine people's openness towards new ideas and experiences. Furthermore, it provide capacities for facilitating social cohesion by instilling a feeling of oneness, and transformative power on existing forms of development. Religious ceremonies, for instance, convey social ethical teachings that foster common identity as well as encourage people to bond and work for common goals. Besides, faith communities possess tremendous capacity for development due to their grassroots networks and unparalleled sway over the poor of the world (Tyndale, 2005). Thus, for the success of the development agenda, it becomes imperative that policy maker take appropriate account of these religious factors.

As earlier explicated in the Christian and Buddhist ethical ideal of compassion, for instance, religious social ethics facilitate dialogue and understanding between and amongst people. This consequently lessens and prevents conflicts as well as protects the rights of the marginalized. It also promotes mutual appreciation of diversity that it in turn fosters positive, constructive engagements, mutual understanding, social inclusion and reconciliation. Besides, by encouraging the participation of minorities and disadvantaged groups in social, political and cultural life, religious social ethics promotes job creation, economic activities and poverty reduction (Gould et al., 2004). It engenders unity and peace, which are essential conditions for social and political stability (Barnett, 1953). Currently, movements within the world religions are key in promoting peace, justice and ecological care an integral aspect of their religious commitment. "Men and women involved in these movements recognize an intrinsic connection between their religious faith and the active concern for the well-being of society and the health of the earth" (Baum: 2005, p. 142).

Experience has demonstrated that developmental initiatives that take into account specific characteristics of societies are most effective (Rakodi, 2011). Besides, they are most likely to create sustainable, inclusive and equitable outcome especially if they also employ a human-centered approach to development. In this sense, religious convictions of people may be the vital to understanding a particular local situation properly. They bear significantly on peoples' attitudes towards consumption and work, the ability to create and manage institutions as well as wealth creation and social networks (Woodcock and Michael 2014). As evidenced by the Islamic teaching 
on wastage and Hinduist prohibition of harming all creatures, religious social ethics can contribute positively to sustainable development. A person, for instance, who has been brought up in an environment where charcoal burning is seen as the best way of earning income will be limited to that mindset due to their culture. Such a person may not even be aware that cutting down trees and burning them has an environmental impact that directly affects a country's economy through loss of revenues through combating natural disasters that come due to climate change. As such, where such Islamic and Hinduist ethical teachings about the environment have been firmly entrenched, such harm and wastage of natural resources may be mitigated. Consideration of these religious views of host communities for developmental projects may thus help actors in this field to formulate and articulate policy objectives that are relevant to specific situations. As contended by Tucker (2005, p. 94), "[s]pecifically, the extension of moral concern to all life forms can be evoked as grounds for stemming the tide of destruction and participating in programmes of conservation."

As earlier alluded to, genuine development is not solely about securing material wellbeing through eradicating poverty. It is also about relating to people who want to be understood and respected in the totality of their being. As evidenced by the work of several faith organizations operating in the developing countries, religious faith inculcates values in education and health care, and inspire reconciliation. Additionally, religion and development policy often pursue similar objectives (Rakodi, 2011). Thus, through cooperation with religious institutions, actors in development can extend their impact and increase their opportunities.

\subsection{Destructive Influence of Religious Social Ethics for Development}

Despite the actual and potential contributions that religious social ethics makes to the unfolding of development, its downside is that it can be a hindrance. As argued by Tyndale (2005, p. 160), "at the institutional level, religions are often seen - not without reason - as divisive, in opposition to modernity or progress, the cause of violence, an obstacle to development, and generally too dangerous for the World Bank to engage with." Religious rigidity, on this front, has indeed proven that it has the effect of initiating and re-enforcing poverty, conflict, inequality and exclusion. For instance, though the functional classes of Hinduism, which we referred to earlier, are ideally free of differences in interests, rights, and privileges, reality in Hindu societies demonstrates the contrary. The system of subdivisions or 'castes' further complicates the class functions in that it transforms them into a discriminatory institution, which is based on birth. For one thing, the brahimins normally gain the most from this system and they are the most powerful. On this score, Max Weber was thus justified in observing that the Vedas are devoid of a 'rational ethic' (Weber, 1958).

Other negative religious traits that have deterred developmental initiatives include exclusion of women from education and propagation of certain views on sexuality as evidenced is Islam. Such practices and tendencies negatively affect development in that some sections of society's involvement in communal affairs is limited. For instance, where women are discriminated against based on gender, when they are confined to house chores and childbearing, they cannot aspire or occupy certain higher position in society due to male domination. They may not be appointed to important and influential positions because of the inferior value assigned to them even though they may be capable to perform in those offices. This affects gender development which is vital for democracy (Ostergaard, 1992), and it augments and perpetuates poverty levels in society.

Religious Complacency in the face of poverty and corruption by public office holders has been a disservice to developmental initiatives. In developing countries, religious leaders have tended to align themselves with the elite clique (Majari, 2009). Much of the nonchalance with regard to public issues is orchestrated by political elites and then given impetus by religious leaders and the faithful lay people. As a result, politicians, political institutions, religious leaders and religious communities have used religion, in some instances, to foster and sustain the structural entrenchment of poverty and corruption in a number of ways.

Though religious bodies in developing countries, such as in Africa, have been channels of foreign material aid for providing poverty-relief and improved welfare to people. However, this measure has not amounted to actual empowerment of the people (Kanbur, 2000). Ultimately, this approach to poverty has a long-term negative impact on the poor, and especially on women, as it has created dependence and detracted them from their own ability to develop latent skills. Furthermore, distribution of relief aid by religious institutions -such as the Christian churches - have to some notable extent provided psychological solace in the face of unjust conditions while political and socio-economic institutions continue to impoverish societies. This direct or indirect cooperation of religious institutions with instruments of socio-political and economic injustice has been at great odds with their social and ethical principles.

Finally, it also worth noting that religions have promoted or justified violence. Religious sparks of violence have been witnessed in the Middle East, India, Sri Lanka and African (e.g. violent attacks by Boko Haram in Nigeria). Normally, these trends have been fuelled by religious fundamentalism that is inherent in all religions. It particularly manifests itself in "a rigid interpretation of their sacred texts, demand internal unanimity, repudiate the mainstream of their own tradition, and refuse to engage in dialogue with outsiders (Baum: 2005, p. 141)." This tendency leads to tolerate violence against the perceived evil, which can be in form of other people or institution. 
The consequent violence is detrimental to social progress and development in that it militates against the prerequisite conditions as highlighted in this treatment.

\section{Conclusion}

For better or for worse, religion is part of human experience as it relates to that which gives ultimate meaning to human existence. The religious impact on economic behavior and consequently development cannot be overlooked. Religion is empirically manifested in form of culture, a way of life that interweaves with public life. Every society in the world today has religious veneers. To the extent that religious social ethics influences patterns of behavior, attitudes towards reality and transformative change, religious culture influences development in similar ways. People's religious beliefs and behavior can contribute to the process of developing and implementing new progressive and transformative ideas in societies. Local religious culture, which includes customs and beliefs, should therefore be considered for sustainable development to be achieved. Religious faith can offer insights into sustainability of development efforts.

Development cannot be reduced to simply material wellbeing or progress. As a human-centered venture, development is all-encompassing. This is so because its realization is dependent on other factors, inclusive of religious social ethics, that characterize human reality and experience. Development, which is compatible with authentic social progress, aims at allowing for the fullest expression of human freedom, which essentially brings into play ultimate meanings of human existence. Religious values, beliefs, and perspectives offer these factors in abundance.

\section{Reference List}

Aangeenbrug - Zinzatie, Marusja (ed.). (2011).Religion \& Development Practitioners' Guide. www.religion-anddevelopment.nl/guide(accessed on 17/03/2014).

Barnett, H. G. (1953). Innovation: The Basis of Cultural Change. New York: McGraw-Hill Book Company.

Baum, Gregory (2005). "Religion and Globalization". Globalization and Catholic Social Thought, edited by John A. Coleman and William F. Ryan, Orbis Books, Maryknoll.

Bilimoria, Purusottama (1993). "Indian Ethics" in A Companion to Ethics.Blackwell Publishing, Malden.

Harris, M. (1975). Culture, People, Nature: An Introduction to General Anthropology. Thomas Crowll, New York.

Hug, James E. (2005). "Economic Justice and Globalization". Globalization and Catholic Social Thought, edited by John A. Coleman and William F. Ryan, Orbis Books, Maryknoll.

John PAul II, Encyclical Letter Sollicitudo Rei Socialis, Pauline Books \& Media, Boston 1987/AAS 80 (1988), 513-586.

Kanbur, Ravi (2000). "Aid, Conditionality and Debt in Africa" in Foreign Aid Development. Ed. Finn Tarp and Peter Hsertholm, New York: Routledge.

Maider, M. (2010). Culture and Development Evolution and Prospect. Bilbao. UNESCO.

Majari, F. C. (2009). When everything else fails: possible roles of the arts in conflict resolution in the Middle East. Fostering peace through cultural initiatives (Conference report, pp. 152-160). Tokyo. Retrieved 25.04.2020 from http://www.jpf.go.jp/j/publish/intel/cul_initiative/pdf/cul_initiative.pdf

Marshall, Ellen Ott (2008). Christians in the Public Square. Nashville: Abingdo Press.

Nanji, Azim (1993). "Islamic Ethics" in A Companion to Ethics. Blackwell Publishing, Malden.

Ostergaard, L. (ed.). (1992). Gender and Development: A Practical Guide. London: Routledge.

Peschke, Karl. H. (1987). Christian Ethics. Vol. II. Theological Publication in India, Bangalore.

Pontifical Council for Justice and Peace (2004). Compendium of the Social Doctrine of the Church, Paulines Publications Africa, Nairobi.

Preston, Ronald (1993). "Christian Ethics" in A Companion to Ethics .Blackwell Publishing, Malden.

Rakodi, Carole (2011). Religions and Development Research Programmes. Working Paper 67. University of Birmingham.

Reus-Smit, Christian and Snidal, Duncan (2008). The Oxford Handbook of International Relations. University Press, Oxford.

Temple William (1942). "Why and How the Church Should Interfere in the Social Order". Christian Social Ethics (1994), edited by John Atherton, The Pilgrim Press, Ohio.

Tyndale, Wendy (2005). "Some Reflections on Dialogue between the World's Religions and the World Bank with Reference to Catholic Social Thought”. Globalization and Catholic Social Thought, edited by John A. Coleman and William F. Ryan, Orbis Books, Maryknoll.

Tucker, Mary Evelyn (2005). "Globalization and the Environment". Globalization and Catholic Social Thought, edited by John A. Coleman and William F. Ryan, Orbis Books, Maryknoll.

Weber, Max (1958).The Protestant Ethic and the Spirit of Capitalism. Scribner New York.

Welch S. and Corner J. (2004). Understanding American Government. Wardsworth: Belmomt.

Woodcock and Michael (2014). Culture, Politics and Development. Policy Research Working Paper 6939. The 
World

Bank:

Washington.

Retrieved

fromhttp://documents.worldbank.org/curated/en/199871468335978774/Culture-politics-and-development on $25 / 04 / 2020$.

https://www.soas.ac.uk/cedep-demos/000 P501 USD K3736-Demo/unit1/page_12.htm (accessed

on 05/04/2020) 